\title{
Alleles of Ppd-1 genes that control sensitivity to photoperiod in a number of bread winter wheat genotypes
}

\author{
A. 0. Bakuma ${ }^{1}$, G. 0. Chebotar ${ }^{1}$, A. V. Tkachuk $^{1}$, S. V. Chebotar ${ }^{1,2^{*}}$, \\ T. Z. Moskalets ${ }^{3}$, V. V. Moskalets ${ }^{3}$
}

${ }^{1}$ Odesa I. I. Mechnikov National University, 2 Dvorianska St., Odesa, 65082,Ukraine, ${ }^{\text {e }}$-mail: s.v.chebotar@onu.edu.ua ${ }^{2}$ Plant Breeding and Genetics Institute - National Center of Seed and Cultivar Investigation, NAAS of Ukraine, 3 Ovidiopolska doroha St., Odesa, 65036, Ukraine

${ }^{3}$ Institute of Horticulture, NAAS of Ukraine, 23 Sadova St., Novosilky, Kyiv, 03027, Ukraine

\begin{abstract}
Purpose. Analysis of the allelic state of Ppd-1 genes, which control sensitivity to photoperiod, in varieties and lines of bread winter wheat, and comparison of the results obtained with field observations on the duration of periods before heading and flowering, whose originators were the Nosivska Breeding and Research Station of the V. M. Remeslo Myronivka Institute of Wheat National Academy of Agrarian Sciences of Ukraine and Poltava State Agrarian Academy of the Ministry of Education and Science of Ukraine. Methods. The following methods were used in the work: DNA extraction, allele-specific PCR, agarose and polyacrylamide gel electrophoresis, analysis of variance. Results. It was revealed that 'Yuvivata $60^{\prime}$ variety has a recessive Ppd-1 genotype and belongs to the III haplotype by a combination of mutations in the structure of Ppd-D1 gene. Line 'L41/95' was heterogeneous by alleles of $P p d-D 1$ gene, which corresponded to the presence of haplotypes III and VII. All other tested cultivars and lines were characterized by alleles $P p d-A 1 b, P p d-B 1 b$ and $P p d-D 1 a$, and assigned to haplotype VII. According to the results of statistical data processing, the duration of the period from May, 1 to heading was the smallest for the variety 'Donskaya polukarlikovaya' in the conditions of both the Forest-Steppe and Polissia-Forest-Steppe regions of Ukraine, the longest - in the varieties 'Yuvivata 60', 'Myronivska 61' and 'L41/95'. The differences between these groups were significant and amounted to 10 days. Conclusions. A breeding material with a high adaptive ability for growing conditions in Polissia-Forest-Steppe zone was studied by the allelic state of the Ppd-1 genes. A low level of polymorphism in the studied varieties and lines was revealed by the alleles of $P p d-1$ genes [12.5\% - Ppd-D1b (III), 12.5\% - Ppd-D1a/b (III/VII), 75\% - Ppd-D1a (VII)], that agrees with the hypothesis that breeders gave a greater preference for the photoperiod-insensitive wheat genotype under Ukrainian conditions. The genotypes with the dominant Ppd-D1a (VII) gene almost completely dominate in the south of Ukraine. At the same time, in northern latitudes, weather conditions negate the advantages of the genotypes with Ppd-D1a gene.
\end{abstract}

Keywords: Triticum aestivum L.; photoperiod-sensitivity genes; allele-specific PCR.

\section{Introduction}

Varieties and lines of bread winter wheat are characterized by different growth rates, which

\section{Alla Bakuma}

https://orcid.org/0000-0001-7190-2210

Galyna Chebotar

https://orcid.org/0000-0002-7465-4678

Angela Tkachuk

https://orcid.org/0000-0002-5670-6446

Sabina Chebotar

https://orcid.org/0000-0002-9130-7272

Tetiana Moskalets

https://orcid.org/0000-0003-4373-4648

Valentyn Moskalets

https://orcid.org/0000-0002-3786-297X enable them to adapt to different climatic and geographical conditions. Global and regional climate changes make it required to increase the adaptive potential of winter wheat plants. The purpose of breeding winter wheat in the Polissia-Forest-Steppe zone is to create varieties adapted mainly for this ecological niche. High adaptability of polyploid wheat is explained by its complex genome characterized by allelic variations and variations in the number of gene copies, which significantly affect the regulation of plant growth and development [1]. The duration of the "sprouts-heading" period of Triticum aestivum $\mathrm{L}$. determines the flowering time, indirectly affects the yield, and thus is one of the most important agronomic traits. 
The onset of heading largely depends on photoperiod sensitivity of wheat plants - the response to the length of daylight hours. In T. aestivum, photoperiod sensitivity is determined by Ppd-1 genes located on homeologous chromosomes 2A, 2B, and 2D [2]. Dominant alleles of these genes shorten the duration of the "sproutsheading" period due to a decrease in the response of plants to the photoperiod under conditions of short daylight hours. Such alleles appeared in the wild-type wheat genotype as a result of mutations (deletions or insertions) in the promoter regions of Ppd-A1, Ppd-B1, Ppd-D1 genes or an increase in the number of copies of $P p d-B 1$ gene [3-6]. Ppd-1 genes belong to pseudoresponse regulator family and play an important role in the control of circadian rhythms due to the increased expression of the CONSTANS (CO) proteins during long daylight hours. CO proteins interact with proteins encoded by the locus that controls FLOWERING TIME (FT), thereby enhancing their expression and inducing flowering. Alleles of Ppd-1 genes, which cause a neutral reaction to photoperiod, activate the genes for vernalization and trigger early flowering at short daylight hours, in some cases even when the requirements for vernalization are not met [7].

The aim of the research is to revealed the alleles of Ppd-1 genes, which control sensitivity to photoperiod, in the varieties and lines of bread winter wheat of the the Nosivska Breeding and Research Station of the V. M. Remeslo Myronivka Institute of Wheat of NAAS of Ukraine (NBRS MIW) and Poltava State Agrarian Academy of the Ministry of Education and Science of Ukraine (PSAA), and comparison of the data of molecular genetic analysis with the data of period of heading and flowering obtained in the field experiments.

The varieties and lines analyzed in the work were tested at the National Centre for Plant Genetic Resources of Ukraine, approved, registered and used in the breeding programs of the PSAA, V. M. Remeslo Myronivka Institute of Wheat of NAAS of Ukraine (MIW), The Plant Production Institute named after V. Ya. Yuriev of NAAS. The study of the molecular genetic characteristics of this bread winter wheat material will enable to characterize its alleles and further conduct marker assisted selection (MAS) for the effective breeding of genotypes with certain combinations of alleles and haplotypes that determine sensitivity to photoperiod.

\section{Materials and methods}

We analyzed varieties and lines of bread winter wheat NBRS MIW ('Yuvivata 60', 'KS1',
'KS22-04', 'L59-95', 'Zoriana Nosivska', 'KS14', 'L41/95'), PSAA ('Ariivka') and control varieties 'Donskaya polukarlikovaya', 'Myronivska 61', provided by V. V. Moskalets, an employee of the Institute of Horticulture of the NAAS. The pedigrees of the used lines are shown in Table 1. Varieties 'Yuvivata 60', 'Zoriana Nosivska' belong to the semi-intensive type for low and medium agronomic background. Variety 'Ariivka' and lines 'L41/95', 'L59-95', 'KS1' are of the universal type, suitable for growing after various predecessors. One of the main parental and maternal components in hybridization variety 'Donskaya polukarlikovaya' is of an intensive type, well-selected, balanced, early maturing, winter and drought-resistant with large-grain size, productive high and stable grain quality.

DNA was isolated from etiolated seedling by the modified method [12]. Nested allele-specific PCR were carried out on a Flax Cycler Amplifier (Analytik Jena, Germany), the PCR conditions are described in publications [3-6]. The nucleotide sequences of primers for the detection of alleles of genes of photoperiod sensitivity are described in detail in the article by Bakuma et al. [13]. Amplification fragments obtained in PCR were fractionated by horizontal and vertical electrophoresis in $1 \%$ agarose gel or in $7 \%$ polyacrylamide gel.

The dates of heading and flowering onset of wheat plants were recorded during field experiments on the basis of the NBRS MIW (Polissia-Forest-Steppe zone) and the Bila Tserkva National Agrarian University of the Ministry of Education and Science of Ukraine (ForestSteppe of Ukraine) for seven years (2010-2017). The experimental field of the Nosivska Breeding and Research Station is located within a specific ecotone of the Dnipro lowland, in the sphere of influence of two physical and geographical zones - Polissia and Forest-Steppe. The soil of the experimental site is leached chernozem, low humus, light loamy.

The experimental field of the Bila Tserkva NAU is located in the central part of the RightBank Forest-Steppe - in the Buzko-Serednodniprovskyi district of the Dnister-Dnipro ForestSteppe province. The soil is typical black one. The placement of the plots is randomized, the repeatability of the experiment is 3-6 times and in different ecological zones varied depending on the homogeneity of the field in terms of soil and relief features, the predecessor, the quality of preparation of the area for sowing, the volume of seed material. The total area of the experimental plot was $12 \mathrm{~m}^{2}$. The predecessors of bread winter wheat were annual cereals and legumes; the cultivation technology is generally 
Pedigree of the studied varieties and lines of bread winter wheat

\begin{tabular}{|c|c|c|c|c|}
\hline No. & $\begin{array}{c}\text { Variety / line } \\
\text { (national catalog number, certificate) }\end{array}$ & Pedigree & $\begin{array}{l}\text { Year of } \\
\text { creation }\end{array}$ & Originator \\
\hline 1 & 'Ariivka' (No. 171136) & ‘Donskaya polukarlikovaya' × ‘K6477/91' & 2007 & PSAA [8] \\
\hline 2 & line 'KS1' (38-95, UA0107961) & ‘Donskaya polukarlikovaya' × ‘K6477/91' & 1995 & NBRS MIW [9] \\
\hline 3 & line 'KS22-04' (UA0108019) & 'Zoriana Nosivska' × 'Myronivska 61' & 2004 & NBRS MIW [9] \\
\hline 4 & line 'L59-95' (UA0108016) & 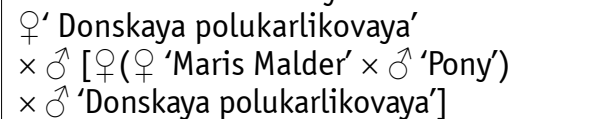 & 1995 & NBRS MIW [9] \\
\hline 5 & $\begin{array}{l}\text { 'Zoriana Nosivska' (UA 0110603, } \\
\text { No. 521) }\end{array}$ & $\begin{array}{l}\left({ }^{\prime} \text { Obrii' } \times{ }^{\prime} \text { Maris Hunstman') } \times \text { 'Maris }\right. \\
\text { Hunstman' }\end{array}$ & 1998 & NBRS MIW [10] \\
\hline 6 & ‘Donskaya polukarlikovaya’ & ('Rusalka' × 'Severodonskaya') & 1983 & $\begin{array}{l}\text { All-Russian Research } \\
\text { Institute of Grain Crops } \\
\text { named after I. G. Kalinenko }\end{array}$ \\
\hline 7 & line 'KS14-05' (UA0123342, No. 1913) & q ‘'Maris Hunstman' × $\widehat{O}\left({ }^{\prime}\right.$ 'Kyianka' $\times$ ‘Pony') & 2005 & $\begin{array}{l}\text { NBRS MIW / Institute of } \\
\text { Horticulture NAAS [9] }\end{array}$ \\
\hline 8 & line 'L41/95' (UA010803, No. 757) & ‘Mirleben' × ‘Poliska 92’ & 1995 & NBRS MIW [9] \\
\hline 9 & $\begin{array}{l}\text { 'Yuvivata } 60 \text { ' (line 'L4639/96') } \\
\text { (UA0108163, No. 1102; } \\
\text { variety in the State Register since } \\
\text { 2014) }\end{array}$ & $\begin{array}{l}\left({ }^{\prime P} \text { Poliska } 90^{\prime} \times{ }^{\prime} \text { Mirleben') } \times\right. \\
\left({ }^{\prime} H o l g r^{\prime} \times{ }^{\prime} P P H 296 \text { ') }\right.\end{array}$ & 1996 & NBRS MIW [9] \\
\hline 10 & 'Myronivska $61^{\prime}$ & $\begin{array}{l}\text { intraspecific hybridization with } \\
\text { subsequent individual selection from } \\
\text { the hybrid population 'Illichivka' } \times \\
\text { 'Hadmersleben } 6508-74 \text { ' }\end{array}$ & 1987 & MIW [11] \\
\hline
\end{tabular}

accepted for the conditions of Forest-Steppe zone [14]. To reveal the beginning of heading and flowering periods the corresponding dates, when we observed flowering and heading in about $50 \%$ of the plants of each plot of a specific wheat genotype, were marked according to the generally accepted method [15, 16].

The climate of the transitional Polissia-Forest-Steppe and Forest-Steppe zones is moderately continental, warm, mild, with sufficient moisture. Growing conditions during 2010-2017 were varied. The increased temperature in May (which is indicated for the period 2010-2014, compared to the long-term norm) and June (2010-2013) did not allow wheat plants to use their maximum potential for heading and flowering phenophases (accumulate the required amount of assimilates) and caused thermal drought, which can negatively affect grain formation and, as a result, yield. October 2013 and 2014 were very dry, only $6-15 \mathrm{~mm}$ of precipitation fell in the Forest-Steppe, and 6-24 $\mathrm{mm}$ in the Polissia-Forest-Steppe. In 2017, the amount of precipitation during the growing season was lower than the average annual indicators - only $56 \mathrm{~mm}$ of precipitation fell in April, May and June. The data were statistically processed using the Statistica 10 software by one- and twoway analysis of variance (ANOVA) [17]. The reliability of the influence of the "Line", "Cultivation zone" factors and their interaction are determined by Fisher's F-criterion for the corresponding factor or interaction.

\section{Results and Discussion}

The breeding material of bread winter wheat analyzed in the article, was created at the Nosivska Breeding and Research Station, located in the conditions of the southern ecotone of Polissia, or Polissia-Forest-Steppe zone. Long-term field studies allowed this material to be differentiated into stable, narrowly and broadly adaptive varieties / lines. The latter group ('Yuvivata 60', 'L4639/96', 'L41/95', etc.) is characterized by a wide range of ecological plasticity, the varieties referred to it have a high mass of 1000 grains, large-grain, and multiflorous. And it should be noted that the use of multiflorous forms of wheat in the breeding process reliably leads to an increase in the number of grains per spike in the following hybrid populations $[18,19]$. They are the ones who most fully realize their genetic potential in the indicated growing zone, based on what they were selected into the Polissia-Forest-Steppe ecotype among the studied varieties and lines of wheat. Alleles of Ppd-A1, Ppd-B1, Ppd-D1 genes were investigated in the genotypes of the studied varieties and lines. No polymorphism was found in Ppd-A1 locus. According to results of the electrophoresis of the amplification fragments obtained by allele-specific PCR, the presence of $P p d-A 1 b$ allele was revealed, what means the absence of $1085 \mathrm{bp}$ deletion in the promoter region (Fig. 1a). In addition, the recessive allele $P p d-B 1 b$ was detected in all studied varieties 
and lines. The resulting PCR product was 1299 $\mathrm{bp}$, what indicates the absence of $308 \mathrm{bp}$ insertion in the promoter region (Fig. 1b). At the same time, fragments of $223 \mathrm{bp}$ and $425 \mathrm{bp}$, which define three and four copies of Ppd-B1 in the genotype, respectively, and which presence lead to decrease in sensitivity to the photoperiod were not found. (Fig. 1c, d).

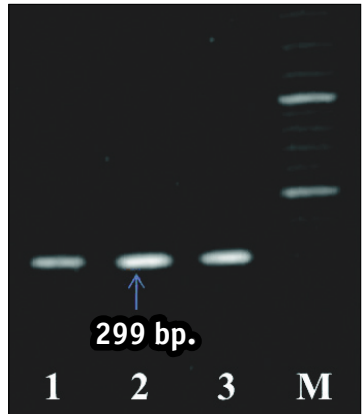

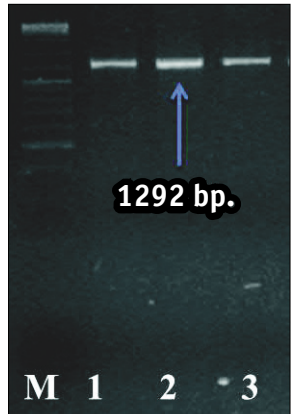

b

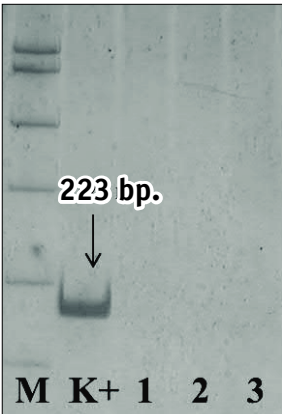

C

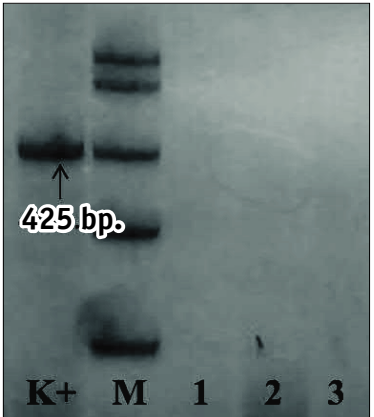

d

Fig. 1. Electropherogram of amplification fragments obtained by PCR of DNA of varieties / lines with allele-specific primers:

a) Ppd-A1b: 1 - 'Ariivka'; 2 - line 'KS1'; 3 - line 'KS22-04'; M - molecular weight marker ladder mix;

b) Ppd-B1b: 1 - 'Ariivka'; 2 - line 'KS1'; 3 - line 'KS22-04'; M - molecular weight marker ladder mix;

c) three copies Ppd-B1 type of 'Sonora 64': 1 - 'Ariivka'; 2 - line 'KS1'; 3 - line 'KS22-04'; K+ - 'Elehiia Myronivska'; M - molecular weight marker pUC19/MspI; d) four-copy Ppd-B1 type 'Chinese Spring': 1 - 'Ariivka', 2 - line 'KS1',

3 - line 'KS22-04'; K+ - 'Struna Myronivska'; M - molecular weight marker pUC19/MspI.

The recessive allele $b$ was identified in the genotype of 'Yuvivata 60' variety by $P p d-D 1$ gene. Line 'L41/95' turned out to be heteroge- neous at this locus. In other varieties and lines of bread wheat, the dominant allele Ppd-D1a was detected (Fig. 2).

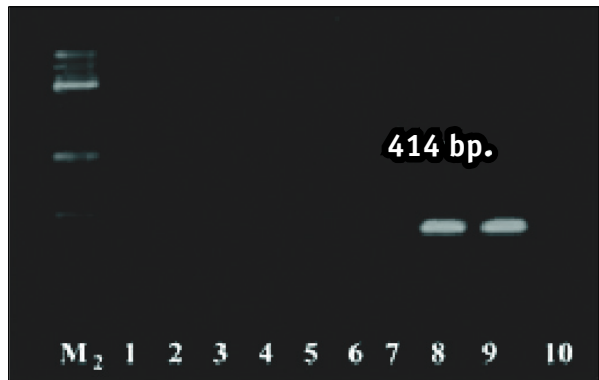

a

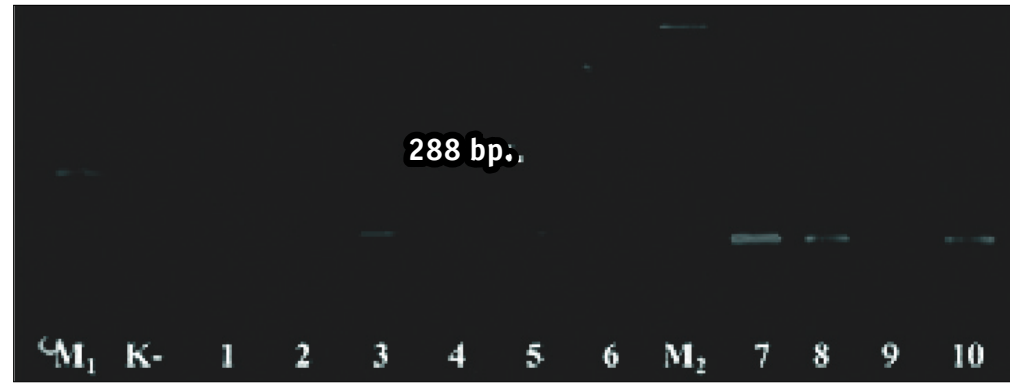

b

Fig. 2. Electropherogram of amplification fragments obtained by PCR with a pool of DNA isolated from five kernels of varieties / lines, with allele-specific primers:

a) Ppd-D1b: 1 - 'Ariivka'; 2 - line 'KS1'; 3 - line 'KS22-04'; 4 - line 'L59-95'; 5 - 'Zoriana Nosivska'; 6 - 'Donskaya polukarlikovaya'; 7 - line 'KS14'; 8 - line 'L41/95'; 9 - 'Yuvivata 60'; 10 - 'Myronivska 61'; $\mathrm{M}_{2}$ - molecular weight marker ladder mix; b) Ppd-D1a: 1 - 'Ariivka'; 2 - line 'KS1'; 3 - line 'KS22-04'; 4 - line 'L59-95'; 5 - 'Zoriana Nosivska'; 6 - 'Donskaya polukarlikovaya; 7 - line 'KS14'; 8 - line 'L41/95'; 9 - 'Yuvivata 60'; 10 - 'Myronivska 61'; M - molecular weight marker pUC19/MspI; $M_{2}$ - molecular weight marker ladder mix.

$P p d-D 1 b$ allele in 'Yuvivata 60' variety and in 'L41/95' line was most likely inherited from the 'Mirleben' donor variety, where this allele was found earlier [20]. In addition, the second parental form of 'Yuvivata 60' cultivar is 'Poliska 90', which carries allele $b$ of the Rht 8 dwarfing gene [21]. This suggests that the cultivar is recessive in Ppd-D1 gene, since the dominant Ppd-D1a allele is usually inherited together with allele $c$ of the Rht8 dwarfing gene. 'Donskaya polukarlikovaya' variety was also studied and involved in the pedigree of 'Ariivka' variety, 'KS1' and
'L59-95' lines. It has the Ppd-D1a allele in the genotype, which causes a neutral reaction to photoperiod. Analysis of the origin of 'Zoriana Nosivska' variety suggests that Ppd-D1a allele is inherited from 'Obrii' variety [22].

Currently, on the basis of the molecular structure of $P p d-D 1$ gene, ten functionally distinctive haplotypes are distinguished. They control different levels of gene expression and have different effects on the duration of the "sprouts-heading" period [23]. Using allele-specific markers in the genotypes of the studied 
plants, the presence of mutations in the nucleotide sequence of $P p d-D 1$ gene-insertions of $24 \mathrm{bp}$ and $15 \mathrm{bp}$, separated by $105 \mathrm{bp}$ in the intact promoter region (Fig. 2a), insertion of MLE (mariner-like elements) type transposons in intron 1 (Fig. 3a), no 5 bp deletion in the seventh exon (Fig. 3b) and deletion of $16 \mathrm{bp}$ in the eighth exon (Fig. 3c) was detected.

The combination of these mutations with a key deletion of $2089 \mathrm{bp}$, which causes a neutral

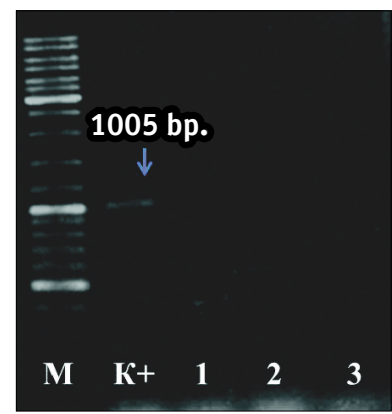

a

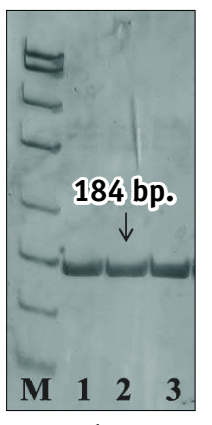

6

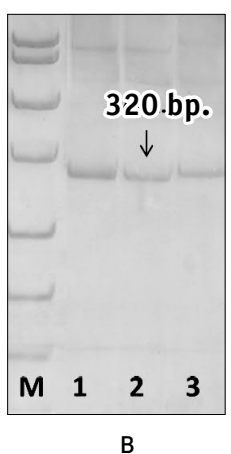

B
Fig. 3. Electrophoregram of the distribution in $7 \%$ PAG of amplification fragments obtained by PCR with DNA of varieties / lines and allele-specific primers:

a) Ppd-P5 (TE insertion located in intron 1): 1 - 'Ariivka'; 2 - line 'KS1'; 3 - line 'KS22-04'; K+ - 'Zymoiarka'; $M$ - molecular weight marker ladder mix;

b) Ppd-P7 (deletion of 5 bp in exon 7): 1 - 'Ariivka'; 2 - line 'KS1'; 3 - line 'KS22-04'; M - molecular weight marker pUC19/MspI; c) Ppd-P3 (insertion of $16 \mathrm{bp}$

in exon 8): 1 - 'Ariivka'; 2 - line 'KS1'; 3 - line 'KS22-04'; $\mathrm{M}$ - molecular weight marker $p U C 19 / \mathrm{MspI}$. reaction to photoperiod, allowed the genotype of 'Yuvivata 60' to be assigned to haplotype III, and line 'L41/95' heterogeneous at the Ppd-D1 locus, to haplotypes III and VII. Other varieties and lines are assigned to haplotype VII (Table 2). According to Guo et al. [5], haplotype III is characterized by a lower level of expression of Ppd-D1 gene compared to haplotypes I-VI, which leads to a later heading of plants and can be an advantage when grown in northern latitudes, since it will allow plants to avoid the effect of low temperatures in case of flowering in late spring - early summer. Currently, no studies of the expression level of haplotype VII of Ppd-D1 gene have been carried out.

As a result of one-way analysis of variance of field experiment data on heading and flowering rates, a significant influence of the "Line" factor $(P=0.01)$ on the investigated traits was revealed. The earliest heading under the conditions of the Forest-Steppe and Polissia-Forest-Steppe of Ukraine was typical for the variety 'Donskaya polukarlikovaya', the latest for varieties 'Yuvivata 60', 'Myronivska 61' and line 'L41/95' (Table 3). The difference between the indicated groups was significant - about 10 days. But in terms of yield, the studied lines differed among themselves within the margin of error.

Among the varieties and lines with 'Donskaya polukarlikovaya' variety in the pedi-

Table 2

Ppd-D1 haplotypes of the studied wheat varieties and lines

\begin{tabular}{|c|c|c|c|c|c|c|c|c|}
\hline $\begin{array}{l}\text { Allele } \\
\text { Ppd-D1 }\end{array}$ & Variety, line & $\begin{array}{c}\text { Ppd-D1 } \\
\text { haplotype }\end{array}$ & $\begin{array}{c}\text { Number } \\
\text { of } \\
\text { varieties }\end{array}$ & $\begin{array}{l}24 \mathrm{bp}+15 \mathrm{bp} \\
\text { insertion in } \\
\text { the promoter }\end{array}$ & $\begin{array}{l}2089 \mathrm{bp} \\
\text { deletion in the } \\
\text { promoter }\end{array}$ & $\begin{array}{c}\text { TE } \\
\text { insertion } \\
\text { in intron } 1 \\
\end{array}$ & $\begin{array}{c}5 \mathrm{bp} \\
\text { deletion } \\
\text { at exon } 7\end{array}$ & $\begin{array}{c}16 \mathrm{bp} \\
\text { insertion } \\
\text { at exon } 8\end{array}$ \\
\hline$b$ & 'Yuvivata 60 ' & III & 1 & absent & absent & present & absent & absent \\
\hline$a$ & $\begin{array}{l}\text { 'Ariivka', } \\
\text { 'KS11', } \\
\text { 'KS22-04', } \\
\text { 'L59-95', } \\
\text { 'Zoriana Nosivska', } \\
\text { 'Donskaya polukarlikovaya', } \\
\text { 'KS14', 'Myronivska 61' }\end{array}$ & VII & 8 & absent & present & present & absent & absent \\
\hline$b / a$ & line 'L41/95' & III/VII & 1 & absent & $\begin{array}{l}\text { absent / } \\
\text { present }\end{array}$ & present & absent & absent \\
\hline
\end{tabular}

gree, only line 'L59-95' did not significantly differ from the parent variety in flowering time, which may indicate the presence of other genes in the genotype of these samples that affect the rate of phenophase duration which we do not test in this work. Also of interest is the rather late heading and flowering of 'Mironivska 61' variety plants (which is characterized by the presence of $P p d-D 1 a$ allele), practically at the level of the photoperiod- sensitive variety 'Yuvivata 60' and line 'L41/95'. The differences may be due to other genetic systems or epigenetic factors. In general, samples with the recessive allele of Ppd-D1 gene tended to later heading and flowering than varieties and lines with a dominant allele. According to two-way ANOVA (Table 4), the factors "Line" and "Growing area" significantly influenced the DH and DF, but not on the yield. In the conditions of Forest- 
Characteristics of the studied varieties and lines of bread winter wheat according to agronomic traits

\begin{tabular}{|c|c|c|c|c|c|c|}
\hline \multirow{2}{*}{ Variety, line } & \multicolumn{3}{|c|}{ Average for 2010-2017 (Forest-Steppe) } & \multicolumn{3}{|c|}{ Average for 2010-2017 (Polissia-Forest-Steppe) } \\
\hline & $\mathrm{DH}$ & DF & Yield, $\mathrm{g} / \mathrm{m}^{2}$ & $\mathrm{DH}$ & DF & Yield, $\mathrm{g} / \mathrm{m}^{2}$ \\
\hline 'Ariivka' & 23.13 & 27.13 & 637.5 & 25.13 & 30.25 & 687.09 \\
\hline 'KS1' & 23.25 & 27.25 & 624.3 & 25.13 & 29.63 & 623.35 \\
\hline 'KS22-04' & 21.50 & 26.38 & 590.6 & 23.88 & 28.25 & 632.68 \\
\hline ‘L59-95’ & 20.63 & 25.00 & 577.8 & 22.50 & 26.63 & 536.36 \\
\hline 'Zoriana Nosivska' & 24.25 & 28.75 & 555.3 & 26.13 & 31.00 & 595.44 \\
\hline 'Yuvivata 60' & 27.25 & 31.88 & 661.4 & 30.25 & 34.50 & 640.54 \\
\hline ‘KS14' & 22.63 & 26.75 & 578.6 & 24.13 & 29.75 & 556.00 \\
\hline ‘L41/95’ & 26.75 & 31.88 & 597.9 & 29.13 & 34.00 & 577.23 \\
\hline ‘Donskaya polukarlikovaya' & 17.25 & 21.50 & 530.0 & 19.00 & 23.00 & 519.59 \\
\hline 'Myronivska 61' & 26.13 & 30.50 & 591.0 & 28.38 & 33.00 & 579.48 \\
\hline $\mathrm{LSD}_{0.05}$ & 3.92 & 3.74 & - & 3.82 & 3.36 & - \\
\hline $\mathrm{LSD}_{0.01}$ & 5.2 & 5.1 & - & 5.06 & 4.47 & - \\
\hline
\end{tabular}

Note. DH - date of heading (starting from the first of May); DF - date of flowering (starting from the first of May).

Table 4

Influence of factors "Line" and "Growing area" factors on the studied traits

\begin{tabular}{|c|c|c|c|c|}
\hline \multirow{2}{*}{ Signs } & \multicolumn{4}{|c|}{ Source of variation, $\mathrm{mS}$} \\
\cline { 2 - 5 } & “Line" & "Growing area" & "Line" $\times$ "Growing area" interaction & Accuracy \\
\hline $\mathrm{df}$ & 9 & 1 & 9 & 140 \\
$\mathrm{DH}$ & $164.92^{* * *}$ & $174.31^{* * *}$ & 0.72 & 15.17 \\
$\mathrm{DF}$ & $179.0^{* *}$ & $211.6^{* * *}$ & 1.2 & 13.2 \\
Yield & 29222 & 5 & 4074 & 22268 \\
\hline
\end{tabular}

** - valid for $p=0.001$

Steppe flowering and heading occurred approximately two days earlier than in the con-

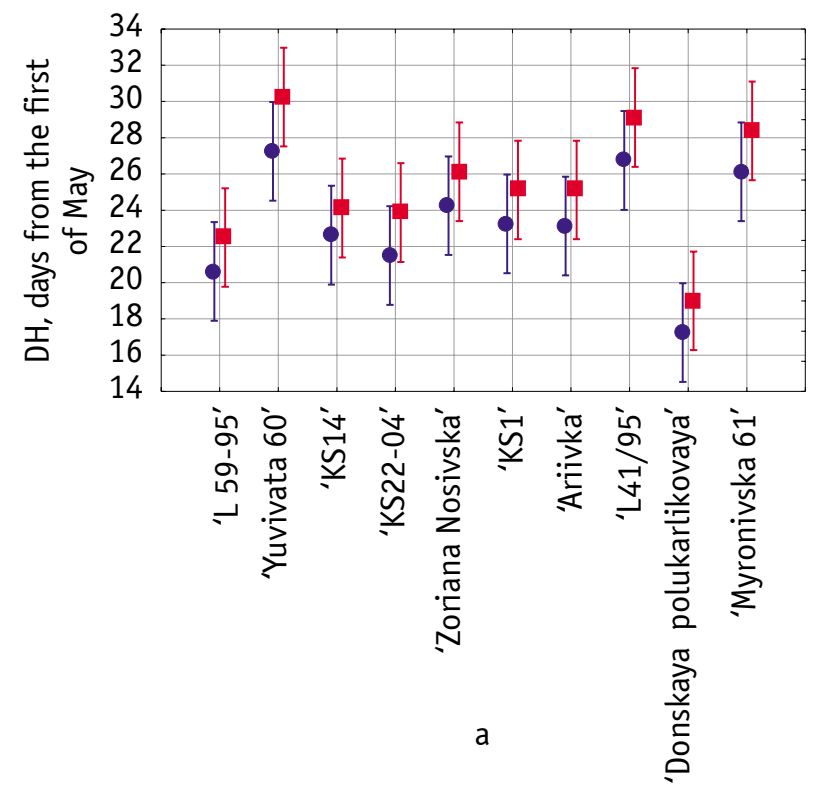

ditions of the Polissia-Forest-Steppe zone (Fig. 4).

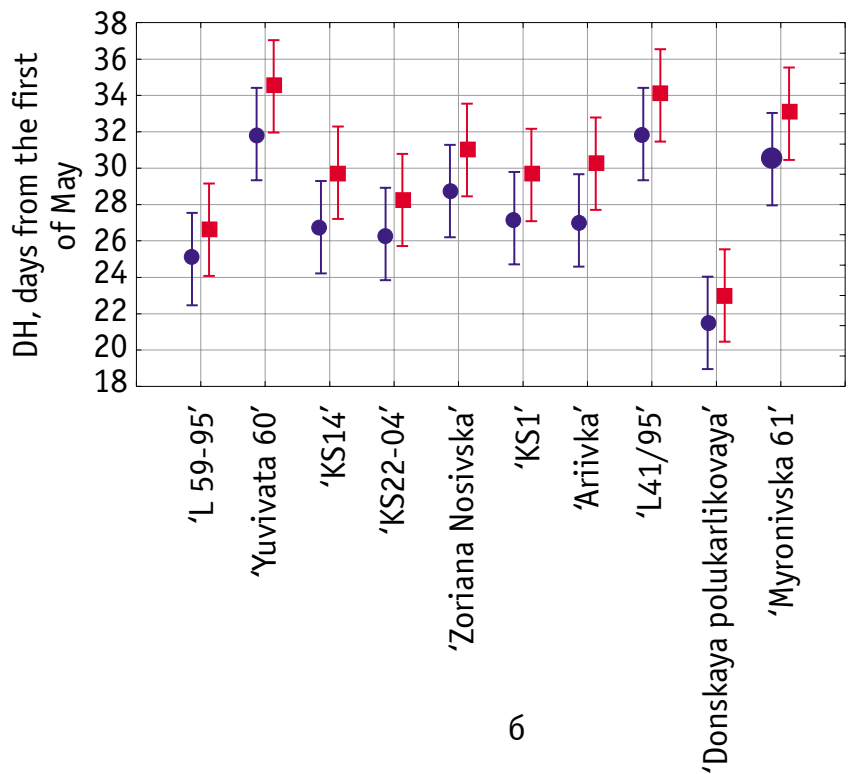

Fig. 4. Time of heading (a) and flowering (b) of the studied lines in the conditions of the Forest-Steppe (blue circle) and Polissia-Forest-Steppe zone (red square)

Note. $\mathbf{n}, \bullet$ - average value; I - variance.

Lines with (Ppd-D1a) and absence of deletion of 2089 bp upstream of the coding region ( $P p d-D 1 b)$, regardless of the cultivation zone, did not significantly differ among themselves in yield, which can be explained by selective breeding, aimed at creating high-yielding varieties. Also, the absence of differences can be influenced by the presence of only one sample with $P p d-D 1 b$ and $P p d-D 1 a / b$ in groups and a fairly high variance in terms of yield (Fig. 5). 


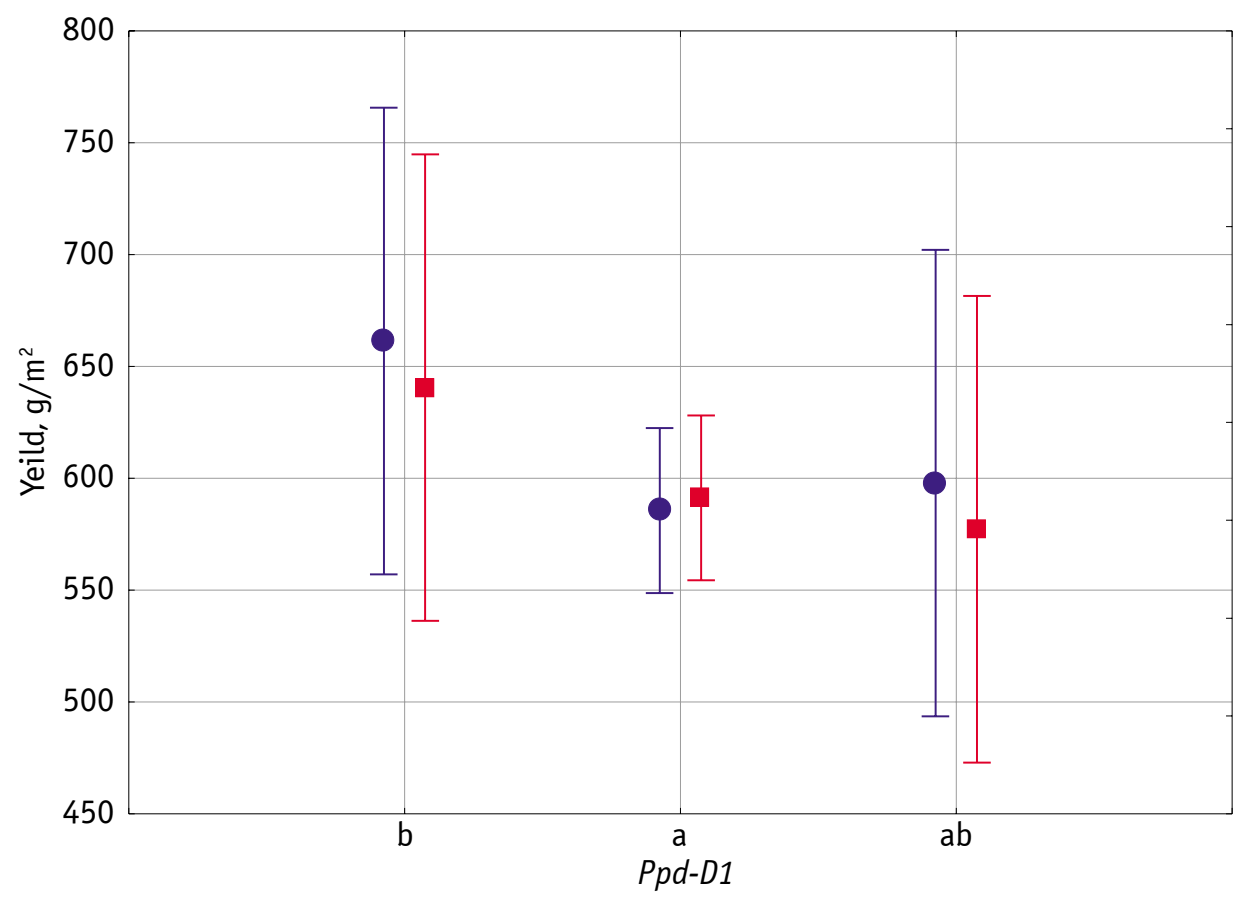

Fig. 5. Productivity of the investigated lines depending on the alleles of the Ppd-D1 gene under the conditions of the Forest-Steppe (blue circle) and Polissia-Forest-Steppe (red square)

Note. $\mathbf{\square}, \bullet$ - average value; I - variance.

\section{Conclusions}

The new varieties and lines analyzed in the work fully correspond to the direction of bread winter wheat breeding for the conditions of Polissia and Forest-Steppe, since they combine high adaptability to unfavorable abiotic factors, productivity, including large grain, multiflowering, 1000-grain weight, etc. In these agroclimatic zones, varieties with Ppd-D1a gene (VII haplotype) prevail. As we have shown earlier, all varieties of the Steppe ecotope [13] assigned to haplotype VII, but among other varieties belonging to the Forest-Steppe ecotope there were carriers of $P p d-D 1 b$ allele [24, 25 ] assigned to haplotypes II, III, and IV, however their percentage was quite small, especially among winter varieties.

During cultivation of new wheat genotypes in Forest-Steppe and Polissia-Forest-Steppe zone, similar trends regarding earlier heading and flowering of plants with reduced sensitivity to photoperiod are observed. So an interesting question remains: What genetic mechanism allows 'Donskaya polukarlikovaya' variety to be the earliest among all the studied samples (even among the varieties with the same Ppd-D1a gene).

However, for the conditions of Polissia and Polissia-Forest-Steppe transition zone there is no need to create varieties with early heading, typical for the variety 'Donskaya polukarlikovaya', because for this ecological niche May conditions are occasionally accompanied by low and negative air temperatures, which causes a complete or partial white spike, sterility of the ear, an increase in the formation of underdeveloped shoots and, as a result, uneven maturation, and decrease in crop productivity.

\section{References}

1. Shi, C., Zhao, L., Zhang, X., Lv, G., Pan, Y., \& Chen, F. (2019). Gene regulatory network and abundant genetic variation play critical roles in heading stage of polyploidy wheat. BMC Plant Biol., 19(6), 6. doi: 10.1186/s12870-018-1591-z

2. Worland, A. J., Appendino, M. L., \& Sayers, E. J. (1994). The distribution, in European winter wheats, of genes that influence ecoclimatic adaptability whilst determining photoperiodic insensitivity and plant height. Euphytica, 80(3), 219-228. doi: 10.1007/BF00039653

3. Beales, J., Turner, A., Griffiths, S., Snape, J., \& Laurie, D. (2007). Pseudo-Response Regulator is misexpressed in the photoperiod insensitive Ppd-D1a mutant of wheat (Triticum aestivum L.). Theor. Appl. Genet., 115(5), 721-733. doi: 10.1007/s00122-007-0603-4

4. Nishida, H., Yoshida, T., Kawakami, K., Fujita, M., Long, B., Akashi, Y., Laurie, D. A., \& Kato, K. (2013). Structural variation in the 5 upstream region of photoperiod-insensitive alleles $P p d-A 1 a$ and Ppd-B1a identified in hexaploid wheat (Triticum aestivum L.), and their effect on heading time. Mol. Breed., 31(1), 27-37. doi: 10.1007/s11032-012-9765-0

5. Guo, Z., Song, Y., Zhou, R., Ren, Z., \& Jia, J. (2010). Discovery, evaluation and distribution of haplotypes of the wheat Ppd-D1 gene. New Phytol., 185(3), 841-851. doi: 10.1111/j.1469-8137. 2009.03099.x

6. Díaz, A., Zikhali, M., Turner, A., Isaac, P., \& Laurie, D. A. (2012). Copy number variation affecting the Photoperiod-B1 and Vernalization-A1 genes is associated with altered flowering time in wheat (Triticum aestivum). PLoS One., 7(3), e33234. doi: 10.1371/journal.pone.0033234

7. Arjona, J. M., Royo, C., Dreisigacker, S., Ammar, K., \& Villegas, D. (2018). Effect of $P p d-A 1$ and $P p d-B 1$ allelic variants on grain 
number and thousand kernel weight of durum wheat and their impact on final grain yield. Front. Plant Sci., 9, 888. doi: 10.3389/fpls.2018.00888

8. Moskalets, V. I., Tyshchenko, V. N., Moskalets, T. Z., Pysarenko, P. V., Hrynyk, I. V., \& Moskalets, V. V. (2019). Environmentally plastic, high-yielding variety of winter common wheat Aryivka. Visnik Centru naukovogo zabezpečennâ APV Harkivs'koï oblasti [Bulletin of the Center for Science Provision of Agribusiness in the Kharkiv region], 26, 96-105 [in Ukrainian]

9. Moskalets, V. I., Moskalets, V. V., \& Moskalets, T. Z. (2014). Characterization of soft winter wheat outgoing material of Nosivska breeding experiment station of NAAS of Ukraine. Visnik Centru naukovogo zabezpečennâ APV Harkivs'koï oblastì [Bulletin of the Center for Science Provision of Agribusiness in the Kharkiv region], 16, 146-163. [in Ukrainian]

10. Moskalets, V. V., Moskalets, V. I., Moskalets, T. Z., \& Pika, Y. M. (2011). Agrobiological characterization of wheat soft winter ecotypes Triticum aestivum L. cultivar Zoriana Nosivska. Visnik Centru naukovogo zabezpečennâ APV Harkivs'koï oblasti [Bulletin of the Center for Science Provision of Agribusiness in the Kharkiv region], 11, 114-120. [in Ukrainian]

11. Vlasenko, V. A, Kochmarskyi, V. S., Koliuchyi V. T., Kolomiiets, L. A., Khomenko, S. 0., \& Solona, V. Yu. (2012). Selektsiina evoliutsiia myronivskykh pshenyts [Selection evolution of Myronivka wheat]. Myronivka: N.p. [in Ukrainian]

12. Pervaiz, Z. H., Turi, N. A., Khaliq, I., Rabbani, M. A., \& Malik, S. A. (2011). A modified method for high-quality DNA extraction for molecular analysis in cereal plants. Genet. Mol. Res., 10(3), 1669-1673. doi: 10.4238/vol10-3gmr1346

13. Bakuma, A. 0., Chebotar, G. 0., Lavrynenko, U. 0., \& Chebotar, S. V. (2019). Allelic status of the Ppd-1 and Vrn-1 genetic systems in winter wheat varieties of the Institute of irrigated agriculture of NAAS Ukraine. Visnik ONU. Biologiâ [Odesa National University Herald. Biology], 24(1), 49-64. doi: 10.18524/2077-1746.2019.1(44).168799 [in Ukrainian]

14. Saiko, V. F. (2004). Modern technologies of growing competitive grain. Zbirnik naukovih prac Nacional'nogo naukovogo centru "İnstitut zemlerobstva NAAN" [Proceedings of the NSC "Institute of Agriculture of NAAS"], Spec. Iss., 26-31. [in Ukrainian]

15. Tkachyk, S. 0. (2016). Metodyka provedennia ekspertyzy sortiv roslyn hrupy zernovykh, krupianykh ta zernobobovykh na prydatnist do poshyrennia $v$ Ukraini [Method for DUS examination of grain, cereal and leguminous varieties in Ukraine]. Vinnytsia: Nilan-LTD. [in Ukrainian]

16. Kulinkovich, S. N., \& Kulinkovich, E. N. (2014). Diagnostika stadiy razvitiya ozimoy pshenitsy po shkale $\mathrm{BBCH}$ [Diagnostics of the stages of development of winter wheat on the BBSN scale: a methodological guide]. Minsk: Nasha Ideya. [in Russian]

17. McDonald, J. H. (2009). Handbook of Biological Statistics. ( $2^{\text {nd }}$ ed.). Baltimore, Maryland, USA: Sparky House Publ.

18. Arbuzova, V. S., Dobrovolskaya, 0. B., Martinek, P., Chumanova, E. V., \& Efremova, T. T. (2016). Inheritance of signs of "manyflowered" common wheat and evaluation of productivity of the spike of $\mathrm{F}_{2}$ hybrids. Vavilovskii Zhurnal Genetiki i Selektsii [Vavilov J. Gen. Breed.], 20(3), 355-363. doi: 10.18699/ VJ16.125 [in Russian]

19. Tsatsenko, L. V., \& Savichenko, D. L. (2018). Multiflowers forms of bread winter wheat as a model object in the research of the reproductive potential of the main ear. Naučnyj žurnal Kubanskogo gosudarstvennogo agrarnogo universiteta [Scientific Journal of KubSAU], 140. doi: 10.21515/19904665-140-024 [in Russian]

20. Wilhelm, E. P. (2011). Genetic analysis of the group IV Rht loci in wheat (PhD. thesis). University of East Anglia John Innes Centre.

21. Chebotar, S. V. (2008). Allelic characteristics of dwarfing genes in the genetic pool of winter wheat varieties of Ukraine. Genetični resursi roslin [Plant Genetic Resources], 6, 96-103. [in Russian]
22. Fayt, V. I., Balashova, I. A., Fedorova, V. R., \& Balinskaja, M. S. (2014). Identification of genotypes Ppd-1 varieties of wheat genetic methods and STS-PCR analysis. Fiziol. Rast. Genet. [Plant Physiology and Genetics], 46(4), 325-336. [in Russian]

23. Zhang, X., Gao, M., Wang, S., Chen, F., \& Cui, D. (2015). Allelic variation at the vernalization and photoperiod sensitivity loci in Chinese winter wheat cultivars (Triticum aestivum L.). Front. Plant Sci., 6, 470. doi: 10.3389/fpls.2015.00470

24. Chebotar, G., Bakuma, A., Filimonov, V., \& Chebotar, S. (2019). Haplotypes of $P p d-D 1$ gene and alleles of $P p d-A 1$ and $P p d-B 1$ in Ukrainian bread wheat varieties. Visnik L'vivs'kogo universitetu. Seriâ biologična [Visnyk of Lviv University. Biological series], 80, 82-89. doi: 10.30970/vlubs.2019.80.10

25. Filimonov, V. M., Bakuma, A. A., Chebotar, G. A., BurdeniukTarasevych, L. A., \& Chebotar, S. V. (2018). PCR-analysis of photoperidous sensitivity genes in bread wheat varieities from Bilatserkovska Experimental Breeding Station. Visn. ukr. tov. genet. sel. [The Bulletin of Ukrainian Society of Geneticists and Breeders], 16(2), 217-226. [in Russian]

\section{Використана література}

1. Shi C., Zhao L., Zhang X. et al. Gene regulatory network and abundant genetic variation play critical roles in heading stage of polyploidy wheat. BMC Plant Biol. 2019. Vol. 19, Iss. 1. 6. doi: 10.1186/s12870-018-1591-z

2. Worland A. J., Appendino M. L., Sayers E. J. The distribution, in European winter wheats, of genes that influence ecoclimatic adaptability whilst determining photoperiodic insensitivity and plant height. Euphytica. 1994. Vol. 80, Iss. 3. P. 219-228. doi: 10.1007/BF00039653

3. Beales J., Turner A., Griffiths S. et al. Pseudo-Response Regulator is misexpressed in the photoperiod insensitive Ppd-D1a mutant of wheat (Triticum aestivum L.). Theor. Appl. Genet. 2007. Vol. 115, Iss. 5. P. 721-733. doi: 10.1007/s00122-007-0603-4

4. Nishida H., Yoshida T., Kawakami K. et al. Structural variation in the 5' upstream region of photoperiod-insensitive alleles Ppd-A1a and Ppd-B1a identified in hexaploid wheat (Triticum aestivum L.), and their effect on heading time. Mol. Breed. 2013. Vol. 31, Iss. 1. P. 27-37. doi: 10.1007/s11032-012-9765-0

5. Guo Z., Song Y., Zhou R. et al. Discovery, evaluation and distribution of haplotypes of the wheat Ppd-D1 gene. New Phytol. 2010. Vol. 185, Iss. 3. P. 841-851. doi: 10.1111/j.14698137.2009.03099.x

6. Díaz A., Zikhali M., Turner A. et al. Copy number variation affecting the Photoperiod-B1 and Vernalization-A1 genes is associated with altered flowering time in wheat (Triticum aestivum). PLoS One. 2012. Vol. 7, Iss. 3. e33234. doi: 10.1371/ journal.pone.0033234

7. Arjona J. M., Royo C., Dreisigacker S. et al. Effect of Ppd-A1 and $P p d-B 1$ allelic variants on grain number and thousand kernel weight of durum wheat and their impact on final grain yield. Front. Plant Sci. Vol. 9. 888. doi: 10.3389/fpls.2018.00888

8. Москалець В. І., Тищенко В. М., Москалець Т. 3. та ін. Екологічно пластичний, високопродуктивний сорт пшениці м'якої озимої «Аріївка». Вісн. ЦНЗ АПВ Харківської області. 2019. Вип. 26. С. 96-105.

9. Москалець В. І., Москалець В. В., Москалець Т. 3. Характеристика вихідного матеріалу пшениці м'якої озимої Носівської селекційно-дослідної станції ІСГМіАПВ НААН України. Вісн. ЦНЗ АПВ Харківської області. 2014. Вип. 16. С. 146-163.

10. Москалець В. В., Москалець В. І., Москалець Т. 3., Піка Ю М. Агробіологічна характеристика екотипу пшениці м'якої озимої Triticum aestivum L. сорту Зоряна носівська. Вісн. ЦНЗ АПВ Харківської області. 2011. Вип. 11. С. 114-120.

11. Власенко В. А., Кочмарський В. С., Колючий В. Т. та ін. Селекційна еволюція миронівських пшениць. Миронівка, 2012. 326 c.

12. Pervaiz Z. H., Turi N. A., Khaliq I. et al. A modified method for high-quality DNA extraction for molecular analysis in cereal 
plants. Genet. Mol. Res. 2011. Vol. 10, Iss. 3. P. 1669-1673. doi: 10.4238/vol10-3gmr1346

13. Бакума А. 0., Чеботар Г. О., Лавриненко Ю. 0., Чеботар С. В. Алельний стан генів систем Ppd-1 та Vrn-1 у сортів озимої м'якої пшениці Інституту зрошуваного землеробства НААН України. Вісник ОНУ. Біологія. 2019. Т. 24, Вип. 1. С. 49-64. doi: 10.18524/2077-1746.2019.1(44).168799

14. Сайко В. Ф. Сучасні технології вирощування конкурентоспроможного зерна. 3б. наук. праць НHЦ «IH-m землеробства УААН». 2004. Спец. вип. С. 26-31.

15. Методика проведення експертизи сортів рослин групи зернових, круп'яних та зернобобових на придатність до поширення в України / за ред. С. О. Ткачик. Вінниця : Нілан-ЛТД, 2016. 82 c.

16. Кулинкович С. Н., Кулинкович Е. Н. Диагностика стадий развития озимой пшеницы по шкале ВВСН. Минск : Наша Идея, 2014. 36 c.

17. McDonald J. H. Handbook of Biological Statistics. $2^{\text {nd }}$ ed. Baltimore, Maryland, USA : Sparky House Publ., 2009. 317 p.

18. Арбузова В. С., Добровольская 0. Б., Мартинек П. и др. Наследование признака «многоцветковость» у мягкой пшеницы и оценка продуктивности колоса гибридов $F_{2}$ Вавиловский журнал генетики и селекщии. 2016. Т. 20, № 3. С. 355-363. doi: 10.18699/VJ16.125

19. Цаценко Л. В., Савиченко Д. Л. Многоцветковые формы озимой мягкой пшеницы как модельный объект в изучении ре- продуктивного потенциала главного колоса. Научный жур нал КубГАУ. 2018. № 140. doi: 10.21515/1990-4665-140-024

20. Wilhelm E. P. Genetic analysis of the group IV Rht loci in wheat: a thesis submitted for the degree of Doctor of Philosophy / University of East Anglia John Innes Centre, 2011. 319 p.

21. Чеботарь С. В. Аллельная характеристика генов короткостебельности в генетическом пуле сортов озимой мягкой пшеницы Украины. Генетичні ресурси рослин. 2008. № 6. C. 96-103.

22. Файт В. И., Балашова И. А., Федорова В. Р, Бальвинская М. С. Идентификация генотипов Ppd-1 сортов мягкой пшеницы методами генетического и STS-ПЦР анализа. Физиология раст. и генетика. 2014. Т. 46, № 4. С. 325-336.

23. Zhang X., Gao M., Wang S. et al. Allelic variation at the vernalization and photoperiod sensitivity loci in Chinese winter wheat cultivars (Triticum aestivum L.). Front. Plant Sci. 2015. Vol. 6. 470. doi: 10.3389/fpls.2015.00470

24. Chebotar G., Bakuma A., Filimonov V., Chebotar S. Haplotypes of $P p d-D 1$ gene and alleles of $P p d-A 1$ and $P p d-B 1$ in Ukrainian bread wheat varieties. Вісн. Львів. ун-ту. Сер. біол. 2019. Вип. 80. С. 82-89. doi: 10.30970/vlubs.2019.80.10

25. Філімонов В. М., Бакума А. О., Чеботар Г. 0. та ін. ПЛР-аналіз генів фотоперіодичної чутливості у сортів м'якої озимої пшениці селекції Білоцерківської дослідно-селекційної станції. Вісн. Укр. тов-ва генетиків і селекціонерів. 2019. T. 16, № 2. С. 217-226.

\section{УДК 577.2:633.1}

Бакума А. 0. ${ }^{1}$, Чеботар Г. 0. ${ }^{1}$, Ткачук А. В. ${ }^{1}$, Чеботар С. В. ${ }^{1,{ }^{*}}$, Москалець Т. $3 .{ }^{3}$, Москалець В. В. ${ }^{3}$ Алельний стан Ppd-1 генів, що контролюють чутливість до фотоперіоду, у низки генотипів пшениці м'якої озимої. Plant Varieties Studying and Protection. 2020. T. 16, № 3. C. 253-261. https://doi.org/10.21498/2518-1017. 16.3.2020.214926

${ }^{1}$ Одеський національний університет імені I. I. Мечникова, вул. Дворянська, 2, м. 0деса, 65082, Україна, "e-mail: s.v.chebotar@onu.edu.ua ${ }^{2}$ Селекційно-генетичний інститут - Національний центр насіннєзнавства та сортовивчення НААН України, вул. Овідіопольська дорога, 3, м. Одеса, 65036, Україна

${ }^{3}$ Інститут садівництва НААН України, вул. Садова, 23, с. Новосілки, м. Київ, 03027, Україна

Мета. Визначення алельного стану генів Ppd-1, що контролюють чутливість до фотоперіоду, у сортів та ліній пшениці м'якої озимої Носівської селекційно-дослідної станції Миронівського інституту пшениці ім. В. М. Ремесла НААН (НСДС МІП) і Полтавської державної аграрної академії МОН України (ПДАА), та зіставлення отриманих результатів молекулярно-генетичного аналізу 3 даними польових спостережень щодо строків колосіння та цвітіння. Методи. Виділення ДНК, алель-специфічна ПЛР, електрофорез фрагментів ампліфікації в агарозних та поліакриаламідних гелях, дисперсійний аналіз. Результати. Визначено, що сорт 'Ювівата 60’ має рецесивний генотип $P p d-1$ та належить до III гаплотипу за комбінацією мутацій у структурі Ppd-D1 гена. Лінія 'Л41/95' виявилася гетерогенною за алелями гена $P p d-D 1$, що відповідало наявності гаплотипів III і VII. Усі інші досліджені зразки характеризувалися алелями Ppd-A1b, Ppd-B1b та Ppd-D1a та належали до гаплотипу VII. За результатами статистичної обробки даних тривалість періоду від першого травня до колосіння була найменшою в сорту ‘Донская полукарликовая' в умовах як Лісостепу, так і Полісся-Лісостепу України, найбільшою - у сортів 'Ювівата 60', 'Миронівська 61' та лінії 'Л41/95'. Відмінності між зазначеними групами були достовірними й становили приблизно 10 діб. Висновки. За алельним станом генів $P p d-1$ досліджено селекційний матеріал 3 високою адаптивною здатністю для умов вирощування в перехідній зоні Полісся-Лісостеп. За алелями генів Ppd-1 досліджені сорти та лінії виявили невисокий рівень поліморфізму [12,5\% - Ppd-D1b (III), 12,5\% $P p d-D 1 a / b$ (III/VII), 75\% - Ppd-D1a (VII)], що узгоджується з гіпотезою надання селекціонерами більшої переваги слабкочутливим до фотоперіоду генотипам пшениці в умовах України. Генотипи 3 домінантним алелем Ppd-D1a (VII) в умовах Півдня України практично повністю домінують. Водночас у північніших широтах погодні умови нівелюють переваги, що мають генотипи з Ppd-D1a.

Ключові слова: Triticum aestivum L.; чутливість до фотоперіоду; алель-специфічна ПЛР. 